\title{
A Critical Review on the Sustainable Development Future
}

\author{
Ghanim Kashwani \\ Independent Researcher, Abu Dhabi, UAE \\ Email: ghakas90@gmail.com
}

How to cite this paper: Kashwani, G. (2019). A Critical Review on the Sustainable Development Future. Journal of Geoscience and Environment Protection, 7, 1-11. https://doi.org/10.4236/gep.2019.73001

Received: February 4, 2019

Accepted: March 5, 2019

Published: March 8, 2019

Copyright $\odot 2019$ by author(s) and Scientific Research Publishing Inc. This work is licensed under the Creative Commons Attribution International License (CC BY 4.0).

http://creativecommons.org/licenses/by/4.0/

\begin{abstract}
Government managements in every country, at each stage and from all parts of the world are beginning to classify the criticality of highlighting the challenges of sustainability. The high demand of the philosophy of sustainability is being developed in public policy debates. Analyzing the chances of sustainability is an essential element which goes beyond the nation's local plans. It is hard for any nation to practice sustainability if their own government systems which run the organizations of different sectors are unsustainable. In other words, it is impossible for several industries to easily generate economic, environmental and social significances by updating their strategy or pioneering applications when international marketing motivations exist in the opposite dimension. However, as a result of the high demand of sustainable products in the industry, many of the governments have found themselves to be obligated to align with green strategy and policy to facilitate the shift to a sustainable economy which is more resourceful and reasonable for all the stake holders. The vital role of governments consists of setting robust and sustainable policies to regulate the business mechanism for the individuals and industries. The authors give an example of environmental performers to support their claim. This review paper will highlight the role of the three main players in the Sustainable Development Future: government, industry, and society from a new and integrated perspective.
\end{abstract}

\section{Keywords}

Sustainable Development, Corporate Social Responsibility, Governance Performance, Business Ethics

\section{Introduction}

Government has a prospect and is accountable to adopt a management role by 
producing a more suitable atmosphere in which sustainable businesses can flourish. Accordingly, Rajak (2011) suggests collaborating the public with the private sector to identify all the potential challenges that may be faced during the implementation of sustainability. Rajak believes that to build partnerships for sustainability, governments should progressively cooperate with all stakeholders, such as private sectors and society members. This could potentially lead to two different results, depending on the government's efficiency. Even if the government distinguishes its duties in these partnerships, assumes a controlling role and reduces the autonomy of the private sector, this can still be circumvented if they commit to their legislative role solely via strategies, laws, and regulations (Tayab et al., 2018). Even in this specific role, the government should extend their knowledge about sustainable enterprise continuously to set an updated and adaptive model and framework. In fact, governments should be conscious of the alternatives and suitable apparatuses of handling sustainable businesses which suit the stakeholders at different stages with respect to their economic needs (Steurer, 2010).

Additionally, according to Bondy et al. (2012), developing a sustainability policy is not a simple and direct task for governments where there are numerous examples of fragmented policies in the advanced industrial countries. The authors believe that this could be avoided by developing holistic and integrated sustainability schemes that embed the major industrial challenges. These major challenges can be extracted from the international sustainability gatherings, such as the Gs Summit series, World Sustainability Development Summit series, and the Organisation of the Petroleum Exporting Countries (OPEC) Environment meetings. In their study, Lai et al. (2016) highlight the eminence of having more sustainability-active government which can meet the public and private sectors' expectations. For example, both the public and private sectors are willing to aid the government to recognise the factors that affect and address sustainability as the main element of social equity. Furthermore, the social responses for many government sustainability initiatives were positive and enthusiastic because of the need and expectations of the green products. Environmental Tax Reform (ETR) can be a good example to explain this pattern. When ETR was introduced, some of the behavioural economic scholars had thought that it might impact the economic growth and then negatively reflect back on the stakeholders. However, this did not happen - the impact was minimal and the industries started looking for new sources of energy to be utilised, such as solar and wind energies. Fox et al. (2002) believe that these initiatives were successful in the rigour of sustainability because of various reasons. The key reason is the clarity and coherence of the ETR that ease the implementation and the contribution of the stakeholders. The authors comment that a similar concept of ETR has failed in other countries because of the ambiguity in the guidelines of the regulations. According to Khan et al. (2015), there are many political reasons that could benefit from not embracing natural capitalism and delaying these sustainability in- 
itiatives. For example, in Germany, before the implementation of ETR, many approval processes were carried out which affected the energy markets, e.g., fluctuation in the price of oil and gas. As a result, the $\mathrm{CO}_{2}$ emission consumption increased because of the absence of a reasonable framework for the public and private sectors. Khan et al. (2015) suggest that society is not capable to handle distribution policies regarding implementing sustainability in its industries. The shift towards sustainability is a chief change which requires a commitment and uplift to all the contributors within stakeholders from the governments especially in the initial stages.

\section{The Industry Role}

From my understanding and industrial experience, I do believe in the pivotal role of the industrial corporate companies, apart from the governments, to secure a sustainable future for the upcoming generation. For example, companies have a bulky stimulus on the economy and stakeholders without hesitation. It is difficult to implement a sustainable development plan without sustainable industrial corporations. That is, according to Stacchezzini et al. (2016), senior management plays an important role in shaping the future of sustainability development in stakeholders' parties, such as society members. Management actions are grounded in decision-making judgements which are extracted from reference themes such as business polices and approaches that form the business model and the organisational growth of a company. Unsustainable administration outcomes that ignore societal and environmental concerns could delay the organisation's improvement towards the sustainability markets. For instance, Kot and Brzezinski (2015) state that an organisation's sustainability plans are vital to sustainable progress and for an effective guidance of a corporation through green economic requirements under sustainable marketplace circumstances. The notion that corporations are established for financial growth requires organisations to advance most of its societal commitment with respect to their economic targets. Company sustainability strategies have a major task to simultaneously identify both financial sustainability and the social aspect of sustainability (Kashwani et al., 2018). To reach this stage, we must combine the target and purpose of a business example for sustainability. Several scholars such as Lozano et al. (2015) claim that a business model for sustainability can be shaped by highlighting green business market factors. The authors claim that to create business models strategically, innovative activities as voluntary engagement with the stakeholders must be adopted from the senior management. However, many of the organisations have several questions about the use of their business plans and strategies at the full potential to contribute to sustainable development. For example, according to Ortas et al. (2015), first, the organisation has to understand the concept of a voluntary activity with the intent to contribute to solve the societal challenges. These are planned events that are more than simply responses to procedures and lawful implementation or methods to meet the eco- 
nomic targets of the business plans. Simultaneously, the authors suggest this activity should lead to a constructive corporate outcome and progressive financial contribution to the company's achievement which can be highlighted in a realistic approach. These strategies have several advantages such as being cost effective, increase in the effectiveness of green markets, enhanced productivity, and better reputation. Idemudia (2011) states that having business case to implement sustainability is usually categorised by generating commercial success through these social and sustainability activities. Additionally, the author states that condensing these attributes could aid the forming of the structure of the business case in industrial organisations in terms of roles and values with respect to its sustainable development needs. However, the challenge will always persist if the industrial organization has the will and intention to contribute towards the social and environmental issues within the stakeholders' interests. Yet, many social-sustainability scholars (Jamali, 2010; Kashwani, 2013) believe that even if there is an intention to embed parameters of sustainability in the company, a failure or defect of sustainable business case could occur. To reach this enabling equation, the business corporate strategies should be subsided through economical and sustainable mind-set. In other words, strategic goals and processes and commercial frameworks of the organization ought to be oriented towards a sustainable management. According to these crucial expectations, many scholars inquire how planned sustainability administration can attribute to generate business models for sustainability and how financial framework modernisation can serve in this green mechanism (Amui et al., 2017; Baden \& Harwood, 2013)).

\section{The Society Role}

Furthermore, other scholars believe that the main key player in boosting the sustainability in the stakeholders is society. For instance, according to Lock and Seele (2016); Dobers and Halme (2009), we need to impose the culture of sustainable consumption to enforce strong sustainability. Therefore, a conversation between the business sectors and society members is required to draw the required patterns of sustainable consumption strategies. Accordingly, many researchers suggest sustainable consumption can be considered one of the most pivotal elements of the Corporate Social Responsibility (CSR). To foster this element, public should highlight and demonstrate their interests and needs through several approaches, such as media. Sierra-García et al. (2015) explain that the communication technologies, e.g., social media, can play a critical role in highlighting the damages of non-sustainable business towards its citizens, government authorities, and investors in the long run. Furthermore, the authors believe that when society start explicating their sustainable demand, the business sector will reshape the current economic development to develop new concepts and functions such as circular economy. Consequently, senior management of industrial organisations will have a better monitoring system towards the sustainable business behaviour with respect to the CRS requirements. Del Mar 
Alonso-Almeida et al. (2014) state that the central notion of the CSR perception is that corporates should take more responsibility in society than only manufacturing products and making profits; they should embrace society's sustainability ambitions in which the business sector should organise non-profit-oriented events to improve the well-being among its society members.

On the other hand, Beynaghi et al. (2016) believe in the importance of dividing the CRS functions into two categories: internal and external exercise. For the internal events, the activities usually include the involvement of the society members with government regulation and policies such as reviewing and giving feedback about the current sustainability regulations. According to the authors, this may enhance and ease the enforcement of the sustainability regulations between all the stakeholders since they have a direct contribution to these regulations. For instance, Murguía and Böhling (2013) provide an insight on how to reduce the environmental issues by involving society members. According to them, in many European countries, when the society members were involved in the adoption of pollution prevention and redesigning of product-manufacturing strategies, a major reduction of negative environmental impacts of hazardous emissions in the communities was observed. According to the authors, these CRS internal activities will help to achieve more beneficial environmental results and eventually, society and other stakeholders will be familiarised with the reduce, recycle, and reuse culture. Moreover, external events will be more philanthropic and support the Public Interest Group (PIG) to solve the current sustainability challenges at the national and international level. In other words, external exercises have lesser shares than the internal ones. Furthermore, Bansal (2005) suggests that suggests that internal and external exercises will unite and equally attribute as one ecological factor to further the sustainable development. According to Bansal, this can be achieved directly by having external conservation events and indirectly by saving natural capitals as inputs for the business projects.

Aguilera et al. (2007) present another classification of CSR with respect to the attribution to sustainability development. For example, CSR can be divided into four tiers: pure-commercial-oriented, short-term beneficial for the stakeholders, long-term beneficial for the stakeholders, and sustainability-orientated. For the pure commercial-oriented level, the authors highlight that in these kinds of activities and events, the main criterion of selection is solely profitability. Then, for the short-term beneficial, the authors state that generally, these events have an immediate benefit for the society members-for instance, organising events that go beyond the normal commercial patterns to aid stakeholders' members to reach short and measurable sustainability goals. Regarding the long-term beneficial activities, Banerjee (2008) believes that forming an educational event can be the best illustration for this type of CRS activity. This can be implemented by providing sustainability courses that tackle the Sustainable Development Goals (SDGs), especially in sustainable consumption and production. According to the 
author, once the awareness of the society members is increased, the business sector can laterally shift towards the sustainability requirements in their businesses as a genuine response. Furthermore, when this phase occurs, business motivations and drives will be found which could create new business disciplines and new job opportunities. Lee (2008) agrees and adds that when the social and environmental factors combine with the business-driven factors, a better implementation of CSR will take place. Consequently, all the stakeholders will be ready to move to the next and last level of the CRS activity: sustainability-oriented. At this level, Lee believes that the usual concept of profitability for most of the industrial organisations will be to transform into green profitability. Thus, the financial investment for most of the senior management of the firms will turn to be more sustainable and greener.

\section{The Collaboration between Government, Industry and Society}

Furthermore, many scholars believe that the collaboration between the society members and industrial organisations is very essential to enrich the sustainability culture presently and in the future. Accordingly, all the parties of the stakeholders should be conscious about the resource efficiency concept and its applications. According to Govindan et al. (2014), without the application of the resource's efficiency concept, reaching the sustainable consumption goals would be almost impossible. The authors justify this claim by highlighting the role of sustainable production which is directly associated with the resource's management. If the first step of the sustainable consumption-the production phase-has difficulty in handling its resources, the whole cycle of the consumption will be impacted. Govidan et al. believe that the inefficient resources management that occurs because corporations deal with financial risk and stand through social activities rather than engaging with sustainability core issues. For example, most of the industrial organisations need to ask themselves better questions to achieve optimum green performance. Instead of asking how much profit I would generate if I launch this business, the question should be what I can attribute to my community if I start this business. This mentality will lead to exponential growth in the future of sustainability between the stakeholders. Additionally, to promote economic sustainability development, business is not simply business. In fact, Luthra et al. (2016) emphasise on the importance of government's intervention in promoting sustainability for several reasons. The key reason is that corporations' main aim is to make profits and so their insights on attaining sustainable development will be subjected to other business strategies. The authors trust that the individual businesses can play a preliminary role in boosting the sustainable consumption because according to them, all economical solutions start at the individual level. In other words, as a society member, you represent the main consumer of the corporation's products which gives you the power to be the key influencer in the consumption cycle. This can be a 
great substitute for the individual than being a prisoner of the business system. The high level of individual autonomy is the main advantage against the corporations that are under many unsupported regulations regarding their sustainable development. Scholars such as Kuckertz and Wagner (2010) believe that an individual, through their awareness and consumption behaviour, can play a dynamic role in forming green business values and attaining sustainability-related goals. Additionally, when the individual in society contributes to the sustainable development by participating in the business sector, the educational system modifies itself to be more sustainability-oriented.

Furthermore, according to Bénabou and Tirole (2010), the community stresses on individual and CSR as a substitute reaction to usual business which makes major defects in implementing sustainability in society. The authors suggest several methods which can enrich the role of the individual in their CSR, especially with the empowerment of Non-Governmental Organisations (NGOs): first, to ease the accessibility to major cooperation for the society members; second, raise public awareness regarding the long-term cost of key environmental issues such as the rise in sea level; finally, familiarisation, social responsibility among all the stakeholders.

\section{Conclusion}

As future recommendation, I suggest focusing more on the implementation of the CRS mechanism. CSR has more standing in today's corporate life; it has its unique characterizations and contributions towards sustainability. Nevertheless, internal CSR exercises, most of whose resources are consumed, primarily emphasise on relative sustainability activities. However, on the other hand, external activities concentrate on the core concept of the sustainability. Through both these types of CRS activities, the consumption methodology and patterns could witness a lateral shift in the favour of the sustainability goals.

In conclusion, all the stakeholders should adopt the accountability and responsibility to implement sustainability in the present and secure it for the future. The reinforcement of sustainable activities should be started from the government authorities in regulation and policy formats which can provide the guidelines for others such as the corporates as shown in Figure 1. Regarding the business and industrial sectors, the senior management in these organisations should believe in contributing to society. Thus, the driving factors for business application will be oriented more toward the CSR. Yet, this is not enough as the sustainability scholars highlight in their review studies. They believe in the importance of having an eco-system to implement sustainability. Thus, I can agree with the following suggestions as approaches to sustain the current movement and to increase it for the future and secure the resources for the next generations (Branco \& Rodrigues, 2008; Courville, 2003):

1) Boost and empower professional contribution with research methods and outcomes and create a joint platform between industry and academia. 


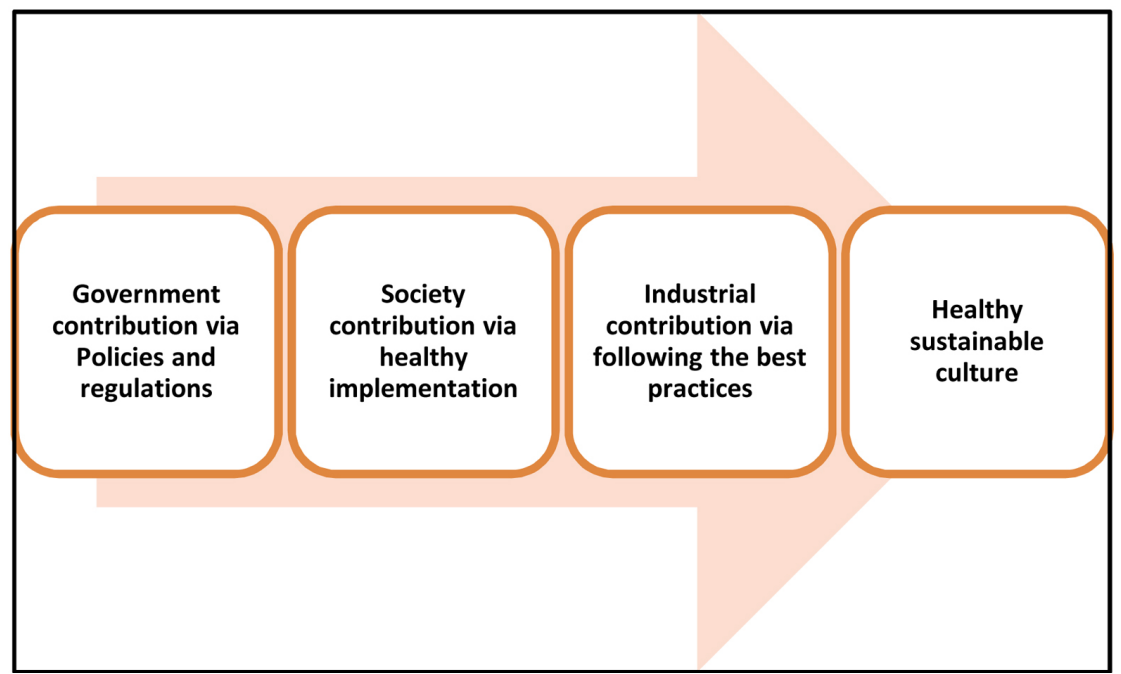

Figure 1. The relationship between government, industry and society.

2) Work to increase the demand for sustainable development through Government's collaboration with external bodies, including: co-professional, commissioning, law-making administrations.

3) Launch a complete strategy to initiate the development of professional ethics and sustainable development across all the business sectors.

4) Actively involve the society in the discussion of knowledge with those working beyond the limitations of standard sustainable development exercises.

5) Work to impact and reinforce the strategy and regulatory environment predominantly through politicisation, to help the Government convey ethical and sustainable outcomes.

6) Team up the government with key industry frames to bring the wider industries in line with mutually agreed standards for ethical and sustainable exercises.

7) Ensure that all teaching staff in the authenticated schools of business have suitable knowledge of ethics and sustainable development.

8) Confirm that an obligation to the public interest, social determination, and sustainable development is essential.

9) Inaugurate plan to develop transparency and liability, including through alignment with the values of the UN Sustainable Development Goals (SDGs) and social responsibility.

10) Advance agendas to build international capability in the built environment area, to help initiative sustainable development and ethics in exercise, ensuring that these are both traditionally and ecologically suitable and socially accountable.

11) Hold accountability to public for its concerns, social aims, and sustainable development purposes.

12) Collaborate with professional organisations to deliver strong-minded leadership on ethics and sustainable development. 


\section{Conflicts of Interest}

The author declares no conflicts of interest regarding the publication of this paper.

\section{References}

Aguilera, R. V., Rupp, D. E., Williams, C. A., \& Ganapathi, J. (2007). Putting the S back in Corporate Social Responsibility: A Multilevel Theory of Social Change in Organizations. Academy of Management Review, 32, 836-863.

https://doi.org/10.5465/amr.2007.25275678

Amui, L. B. L., Jabbour, C. J. C., de Sousa Jabbour, A. B. L., \& Kannan, D. (2017). Sustainability as a Dynamic Organizational Capability: A Systematic Review and a Future Agenda toward a Sustainable Transition. Journal of Cleaner Production, 142, 308-322. https://doi.org/10.1016/j.jclepro.2016.07.103

Baden, D., \& Harwood, I. A. (2013). Terminology Matters: A critical Exploration of Corporate Social Responsibility Terms. Journal of Business Ethics, 116, 615-627. https://doi.org/10.1007/s10551-012-1498-9

Banerjee, S. B. (2008). Corporate Social Responsibility: The Good, the Bad and the Ugly. Critical Sociology, 34, 51-79. https://doi.org/10.1177/0896920507084623

Bansal, P. (2005). Evolving Sustainably: A Longitudinal Study of Corporate Sustainable Development. Strategic Management Journal, 26, 197-218. https://doi.org/10.1002/smj.441

Bénabou, R., \& Tirole, J. (2010). Individual and Corporate Social Responsibility. Economica, 77, 1-19. https://doi.org/10.1111/j.1468-0335.2009.00843.x

Beynaghi, A., Trencher, G., Moztarzadeh, F., Mozafari, M., Maknoon, R., \& Leal Filho, W. (2016). Future Sustainability Scenarios for Universities: Moving beyond the United Nations Decade of Education for Sustainable Development. Journal of Cleaner Production, 112, 3464-3478. https://doi.org/10.1016/j.jclepro.2015.10.117

Bondy, K., Moon, J., \& Matten, D. (2012). An Institution of corporate Social Responsibility (CSR) in Multi-National Corporations (MNCs): Form and Implications. Journal of Business Ethics, 111, 281-299. https://doi.org/10.1007/s10551-012-1208-7

Branco, M. C., \& Rodrigues, L. L. (2008). Factors Influencing Social Responsibility Disclosure by Portuguese Companies. Journal of Business Ethics, 83, 685-701. https://doi.org/10.1007/s10551-007-9658-Z

Courville, S. (2003). Social Accountability Audits: Challenging or Defending Democratic Governance? Law \& Policy, 25, 269-297. https://doi.org/10.1111/j.1467-9930.2003.00151.x

Del Mar Alonso-Almeida, M., Llach, J., \& Marimon, F. (2014). A Closer Look at the "Global Reporting Initiative" Sustainability Reporting as a Tool to Implement Environmental and Social Policies: A Worldwide Sector Analysis. Corporate Social Responsibility and Environmental Management, 21, 318-335. https://doi.org/10.1002/csr.1318

Dobers, P., \& Halme, M. (2009). Corporate Social Responsibility and Developing Countries. Corporate Social Responsibility and Environmental Management, 16, 237-249. https://doi.org/10.1002/csr.212

Fox, T., Ward, H., \& Howard, B. (2002). Public Sector Roles in Strengthening Corporate Social Responsibility: A Baseline Study. Washington DC: World Bank.

Govindan, K., Kannan, D., \& Shankar, K. M. (2014). Evaluating the Drivers of Corporate Social Responsibility in the Mining Industry with Multi-Criteria Approach: A Mul- 
ti-Stakeholder Perspective. Journal of Cleaner Production, 84, 214-232. https://doi.org/10.1016/j.jclepro.2013.12.065

Idemudia, U. (2011). Corporate Social Responsibility and Developing Countries: Moving the Critical CSR Research Agenda in Africa Forward. Progress in Development Studies, 11, 1-18. https://doi.org/10.1177/146499341001100101

Jamali, D. (2010). The CSR of MNC Subsidiaries in Developing Countries: Global, Local, Substantive or Diluted? Journal of Business Ethics, 93, 181-200. https://doi.org/10.1007/s10551-010-0560-8

Kashwani, G., Liu, E., \& Nawaz, W. (2018). Kashwani Risk Assessment: New Approach for Oil and Construction. Industries. International Journal, 15, 53-61.

Kashwani, G. (2013). Sustainability of Composite Columns under Repeated Load and Harsh Environment. Master Dissertation.

Khan, Z., Lew, Y. K., \& Park, B. I. (2015). Institutional Legitimacy and Norms-Based CSR Marketing Practices: Insights from MNCs Operating in a Developing Economy. International Marketing Review, 32, 463-491. https://doi.org/10.1108/IMR-01-2014-0017

Kot, S., \& Brzezinski, S. (2015). Market Orientation Factors in Sustainable Development and Corporate Social Responsibility. Asian Journal of Applied Sciences, 8, 101-112. https://doi.org/10.3923/ajaps.2015.101.112

Kuckertz, A., \& Wagner, M. (2010). The Influence of Sustainability Orientation on Entrepreneurial Intentions-Investigating the Role of Business Experience. Journal of Business Venturing, 25, 524-539. https://doi.org/10.1016/j.jbusvent.2009.09.001

Lai, A., Melloni, G., \& Stacchezzini, R. (2016). Corporate Sustainable Development: Is "Integrated Reporting" a Legitimation Strategy? Business Strategy and the Environment, 25, 165-177. https://doi.org/10.1002/bse.1863

Lee, M. D. P. (2008). A Review of the Theories of Corporate Social Responsibility: Its Evolutionary Path and the Road Ahead. International Journal of Management Reviews, 10, 53-73. https://doi.org/10.1111/j.1468-2370.2007.00226.x

Lock, I., \& Seele, P. (2016). The Credibility of CSR (Corporate Social Responsibility) Reports in Europe. Evidence from a Quantitative Content Analysis in 11 Countries. Journal of Cleaner Production, 122, 186-200. https://doi.org/10.1016/j.jclepro.2016.02.060

Lozano, R., Ceulemans, K., Alonso-Almeida, M., Huisingh, D., Lozano, F. J., Waas, T., Lambrechts, W., Lukman, R., \& Hugé, J. (2015). A Review of Commitment and Implementation of Sustainable Development in Higher Education: Results from a Worldwide Survey. Journal of Cleaner Production, 108, 1-18. https://doi.org/10.1016/j.jclepro.2014.09.048

Luthra, S., Garg, D., \& Haleem, A. (2016). The Impacts of Critical Success Factors for Implementing Green Supply Chain Management towards Sustainability: An Empirical Investigation of Indian Automobile Industry. Journal of Cleaner Production, 121, 142-158. https://doi.org/10.1016/j.jclepro.2016.01.095

Murguía, D. I., \& Böhling, K. (2013). Sustainability Reporting on Large-Scale Mining Conflicts: The Case of Bajo de la Alumbrera, Argentina. Journal of Cleaner Production, 41, 202-209. https://doi.org/10.1016/j.jclepro.2012.10.012

Ortas, E., Álvarez, I., Jaussaud, J., \& Garayar, A. (2015). The Impact of Institutional and Social Context on Corporate Environmental, Social and Governance Performance of Companies Committed to Voluntary Corporate Social Responsibility Initiatives. Journal of Cleaner Production, 108, 673-684. https://doi.org/10.1016/j.jclepro.2015.06.089

Rajak, D. (2011). In Good Company: An Anatomy of Corporate Social Responsibility. Redwood City, CA: Stanford University Press. 
Sierra-García, L., Zorio-Grima, A., \& García-Benau, M. A. (2015). Stakeholder Engagement, Corporate Social Responsibility and Integrated Reporting: An Exploratory Study. Corporate Social Responsibility and Environmental Management, 22, 286-304. https://doi.org/10.1002/csr.1345

Stacchezzini, R., Melloni, G., \& Lai, A. (2016). Sustainability Management and Reporting: The Role of Integrated Reporting for Communicating Corporate Sustainability Management. Journal of Cleaner Production, 136, 102-110.

https://doi.org/10.1016/j.jclepro.2016.01.109

Steurer, R. (2010). The Role of Governments in Corporate Social Responsibility: Characterising Public Policies on CSR in Europe. Policy Sciences, 43, 49-72. https://doi.org/10.1007/s11077-009-9084-4

Tayab, M. R., Villapil, S., \& Kashwani, G. (2018). Barrier Analysis \& Strengthening to Eliminate Road Traffic Accidents in Oil Fields. In SPE International Conference and Exhibition on Health, Safety, Security, Environment, and Social Responsibility, Abu Dhabi, Society of Petroleum Engineers, 16-18 April 2018.

https://www.onepetro.org/conference-paper/SPE-190554-MS 